\title{
PENGARUH MOTIVASI BELAJAR TERHADAP HASIL BELAJAR BAHASA INDONESIA SISWA KELAS X SMK MAITREYAWIRA TANJUNGPINANG TAHUN AJARAN 2019/2020
}

\author{
Novita Three Putri Hastoni ${ }^{1}$, Indah Pujiastuti ${ }^{2}$, Legi Elfitra ${ }^{3}$ \\ Pendidikan Bahasa dan Sastra Indonesia, Universitas Maritim Raja Ali Haji \\ Pos-el: novitatriph@yahoo.com
}

\begin{abstract}
ABSTRAK
Penelitian ini bertujuan untuk mengetahui pengaruh motivasi belajar terhadap hasil belajar bahasa Indonesia siswa kelas X SMK Maitreyawira Tanjungpinang tahun ajaran 2019/2020. Objek penelitian adalah siswa kelas X SMK Maitreyawira Tanjungpinang. Populasi dalam penelitian ini berjumlah 121 siswa dan sampel dalam penelitian ini adalah keseluruhan jumlah sampel yaitu 121 siswa. Jenis penelitian ini adalah penelitian ex post facto dengan menggunakan pendekatan kuantitatif. Teknik pengumpulan data yang digunakan yaitu dengan menyebarkan angket motivasi belajar dan pemerolehan hasil belajar siswa. Intrumen penelitian dalam penelitian ini adalah angket motivasi belajar dan hasil belajar. Teknik analisis data yang digunakan adalah statistik nonparametrik dengan menggunakan uji Wilcoxon. Hasil penelitian yang diperoleh yaitu nilai sig. 0,000 $<0,05$ maka dapat disimpulkan bahwa Ha diterima. Artinya, ada pengaruh antara motivasi belajar terhadap hasil belajar bahasa Indonesia siswa kelas X SMK Maitreyawira Tanjungpinang tahun ajaran 2019/2020.
\end{abstract}

Kata Kunci: Motivasi Belajar, Hasil Belajar, Bahasa Indonesia

\section{PENDAHULUAN}

Sistem pendidikan dalam suatu bangsa, memiliki tujuan dalam meningkatkan mutu pendidikan. Dalam meningkatkan mutu pendidikan di Indonesia, tidak terlepas dari dukungan pemerintah, orang tua, guru, serta masyarakat. Upaya pemerintah dalam meningkatkan mutu pendidikan yaitu perbaikan kurikulum pendidikan, SDM, serta sarana dan prasarana.

Meningkatkan mutu pendidikan tidak terlepas juga dari kegiatan belajar mengajar. Kegiatan belajar mengajar merupakan suatu kegiatan yang terikat dan terarah untuk mencapai suatu tujuan. Tujuan tersebut biasanya bisa berupa pemerolehan hasil, yang dikenal dengan istilah hasil belajar. Hasil yang optimal dapat diperoleh apabila kegiatan dilakukan secara sadar dan sengaja agar terorganisasi secara baik. Keberhasilan mutu pendidikan juga bergantung dari bagaimana kegiatan belajar mengajar itu berjalan.

Kegiatan belajar mengajar dapat berjalan dengan baik tidak terlepas dari peran guru dan siswa dalam kelas. Kegiatan belajar mengajar di sekolah, harus berjalan secara sistematis agar dapat menciptakan proses belajar yang efektif. Proses belajar yang efektif mampu memberikan pemahaman yang baik kepada siswa agar dapat diterapkan dalam keseharian.

Proses belajar yang efektif masih kurang terlihat ketika di dalam kelas. Hal ini dilihat berdasarkan hasil pengamatan peneliti di Sekolah Menengah Kejuruan Maitreyawira Tanjungpinang tahun ajaran 2019/2020. Proses belajar mengajar yang kurang efektif terlihat ketika di dalam kelas siswa yang bersikap acuh dan tidak ada persiapan ketika melakukan kegiatan belajar. Hal ini dapat dilihat dari bagaimana siswa memberikan umpan balik 
terhadap guru yang mengajar. Ketika guru menjelaskan atau memberikan pertanyaan kepada siswa, tidak semua siswa yang turut serta dalam mengemukakan pendapatnya. Ketika pembelajaran dimulai, siswa diminta untuk mengemukakan pendapat tentang materi yang akan dipelajari namun siswa tidak mampu mengemukakan. Oleh sebab itu, guru selalu menciptakan cara belajar yang menyenangkan untuk menarik keinginan siswa.

Guru ketika mengajar akan selalu berusahaa menciptakan kondisi kelas yang menyenangkan. Ketika di kelas cara guru mengajar setiap materi berbeda-beda , karena ada kalanya guru memberikan games dalam kegiatan belajar sesuai dengan materi yang dibahas. Namun, seringkali hanya beberapa siswa yang mampu memberikan respon dan tanggapan kepada guru. Bahkan jarang sekali ada siswa yang ingin mengajukan pertanyaan mengenai materi yang dibahas. Padahal setiap akhir pelajaran guru selalu mengingatkan siswa untuk mempersiapkan diri sebelum masuk pertemuan selanjutnya.

Tidak hanya cara mengajar guru yang menyenangkan, pada saat proses mengajar di dalam kelas guru juga menerapkan metode sdan model pembelajaran yang berbeda-beda disetiap harinya guna meningkatkan keinginan siswa untuk belajar. Selain cara mengajar dan metode dan model pembelajaran yang digunakan, sarana dan prasarana sekolah juga dapat memberikan pengaruh terhadap jalannya suatu kegiatan di dalam kelas. Dalam hal ini, Sekolah Menengah Kejuruan Maitreyawira Tanjungpinang, memiliki fasilitas-fasilitas yang nyaman. Mulai dari ruang kelas, internet, papan tulis, infocus serta komputer sebagai media belajar yang cukup baik. Adanya ruangan kelas yang nyaman, seharusnya siswa menjadi lebih bersemangat untuk melaksanakan proses belajar. Namun ternyata, fasilitas yang nyaman membuat siswa menjadi terlena dan tidak semangat belajar. Tak jarang pula ada siswa yang meletakkan kepala di atas meja, berbicara di belakang serta siswa yang izin ke toilet. Permasalahan inilah yang menjadi satu diantara penghambat proses kegiatan belajar mengajar berlangsung.

Kegiatan belajar mengajar dapat berjalan dengan baik juga apabila pada diri siswa memiliki semangat dan dorongan untuk melaksanakannya. Tanpa adanya dorongan dari diri siswa serta guru maka proses belajar mengajar tidak akan berjalan dengan baik. Dorongan dan semangat bisa dari dalam diri (internal) dan juga dari luar (eksternal). Apabila keinginan untuk melakukan sesuatu berasal dari diri seseorang sejalan dengan kebutuhannya maka disebut internal. Namun, apabila keinginan untuk melakukan sesuatu mendapat rangsangan dari luar atau dari orang lain maka disebut eksternal. Oleh karena itu, berdasarkan hal tersebut maka sesorang berarti memiliki dorongan atau semangat yang disebut motivasi.

Motivasi merupakan tonggak utama seseorang untuk melakukan sesuatu. Jika tidak ada motivasi dari diri seseorang maka tujuan yang ingin dicapai tidak akan terlaksana. Motivasi merupakan suatu dorongan dari dalam diri seseorang untuk melakukan sesuatu. Dalam hal belajar siswa akan berhasil jika terdorong dan memiliki kemauan untuk belajar. Tanpa adanya motivasi, proses belajar mengajar tidak akan terlaksana secara maksimal karena kurangnya semangat serta dorongan dari dalam diri atau pun dari luar siswa. Motivasi juga dapat menopang upaya-upaya dan menjaga kegiatan belajar tetap lancar. Namun, tidak hanya dorongan dari dalam diri siswa saja, dorongan dari luar juga turut berperan penting. Akibat dari dorongan atau motivasi tersebutlah yang dapat memberikan pengaruh terhadap hasil belajar siswa.

Hasil belajar yang diperoleh siswa dapat memacu kemajuan yang ingin 
dicapai, karena hasil belajar adalah salah satu tujuan yang sangat penting. Hasil belajar seringkali digunakan sebagai ukuran untuk mengetahui seberapa jauh pemahaman terhadap bahan yang diberikan. Apabila siswa mengetahui hasil yang diperoleh maka siswa akan lebih berusaha untuk meningkatkannya.

Berdasarkan hasil informasi guru mata pelajaran bahasa Indonesia pada saat peneliti melakukan kegiatan praktik pengalaman lapangan (PPL) di SMK Maitreyawira Tanjungpinang, banyak sekali siswa yang memperoleh hasil belajar yang rendah. Padahal seperti yang sudah peneliti jelaskan sebelumnya, bahwa sudah berbagai metode dan model pembelajaran digunakan untuk meningkatkan hasil belajar siswa. Namun, hasil belajar yang diperoleh siswa masih belum baik. Hal tersebut dilihat dari ratarata nilai dalam penilaian tengah semester (PTS) yang diperoleh siswa. Hasil belajar yang diperoleh siswa kelas $\mathrm{X}$ SMK Maitreyawira Tanjungpinang dari jumlah siswa 121 siswa kelas $\mathrm{X}$ tersebut terdapat 51 siswa yang belum mencapai kriteria ketuntasan minimum yang ditetapkan yaitu 70. Sedangkan 70 siswa yang mencapai kriteria ketuntasan minimum.

Tidak hanya itu saja, peneliti melakukan wawancara pada siswa ternyata cenderung permasalahan ini dipengaruhi oleh kurangnya dorongan untuk belajar yang dimiliki siswa pada saat kegiatan belajar mengajar berlangsung. Bahkan ada siswa yang menyampaikan bahwa sekolah bagi mereka hanya untuk mencari teman. Bagi beberapa siswa kegiatan belajar hanya menjadi tambahan ketika berada di sekolah.

Selain itu, ketika ditanyakan mengenai pembelajaran Bahasa Indonesia, mereka berpendapat bahwa bahasa Indonesia merupakan pelajaran yang terlalu banyak materi. Mereka berpendapat, banyak sekali istilah atau bahasa yang jarang sekali terdengar di telinga mereka. Hal ini dikarenakan mereka mayoritas berasal dari keturunan tionghoa, sehingga tidak terbiasa dengan bahasa Indonesia. Mereka juga tidak mendapat dorongan dari orang tua untuk membiasakan berbicara menggunakan bahasa Indonesia. Bahkan di sekolah yang telah diberikan peraturan untuk tidak menggunakan bahasa ibu, mereka masih saja menggunakan ketika tidak ada guru.

Sekolah menerapkan peraturan mengenai larangan siswa untuk menggunakan bahasa ibu dikarenakan agar tidak ada kesalahpahaman dengan guru. Karena, sebagian besar guru yang mengajar bukan berasal dari orang tionghoa. Apabila siswa yang melanggar peraturan tersebut, maka guru berhak memberikan sanksi kepada siswa. Sanksi yang diberikan tergantung guru yang mendapatkan siswa yang menggunakan bahasa ibu tersebut. Namun, biasanya tahap awal guru akan hanya memberikan teguran saja. Akan tetapi, apabila kedapatan untuk yang kesekian kali maka akan diberikan sanksi edukasi. Berdasarkan hal tersebut dan latar belakang di atas, peneliti ingin membuktikan bahwa motivasi belajar dapat memengaruhi hasil belajar siswa. Oleh karena itu, peneliti mengambil judul "Pengaruh Motivasi Belajar Terhadap Hasil Belajar Bahasa Indonesia Siswa Kelas $X$ SMK Maitreyawira Tanjungpinang Tahun Ajaran 2019/2020”. Berdasarkan latar belakang tersebut, maka peneliti membatasi ruang lingkup penelitian yaitu "Pengaruh Motivasi Belajar Terhadap Hasil Belajar Bahasa Indonesia Siswa Kelas X SMK Maitreyawira Tanjungpinang Tahun Ajaran 2019/2020". Adapun tujuan dari penelitian adalah sebagai berikut: Untuk mengetahui gambaran motivasi belajar siswa kelas $\mathrm{X}$ SMK Maitreyawira Tanjungpinang Tahun Ajaran 2019/2020, Untuk mengetahui hasil belajar bahasa Indonesia siswa kelas $X$ SMK Maitreyawira Tanjungpinang Tahun Ajaran 2019/2020 dan Untuk mengetahui 
pengaruh motivasi belajar terhadap hasil belajar bahasa Indonesia siswa kelas $\mathrm{X}$ SMK Maitreyawira Tanjungpinang Tahun Ajaran 2019/2020.

\section{METODE PENELITIAN}

Penelitian ini menggunakan pendekatan kuantitatif. Menurut Sugiyono (2016:7), "Kuantitatif adalah penelitian yang datanya berupa angka-angka dan analisisnya menggunakan statistik". Penelitian ini merupakan penelitian $e x$ post facto

\section{Populasi dan Sampel}

Menurut Sugiyono (2016:80), "Populasi adalah wilayah generalisasi yang terdiri atas objek/subjek yang mempunyai kualitas dan karakteristik tertentu yang ditetapkan oleh peneliti untuk dipelajari dan kemudian ditarik kesimpulan". Selain itu, populasi juga dapat dikatakan sebagai keseluruhan subjek penelitian (Arikunto, 2006:130). Berdasarkan pendapat tersebut, maka populasi dalam penelitian ini adalah siswa-siswi kelas X SMK Maitreyawira Tanjungpinang tahun ajaran 2019/2020 dengan jumlah populasi sebanyak 121 siswa. Kelas X TKJ 1 terdiri dari 28 siswa, kelas X TKJ 2 terdiri dari 25 siswa, kelas X AK 1 terdiri dari 27 siswa, kelas X AK 2 terdiri dari 30 siswa dan kelas X PM terdiri dari 11 siswa.

Penelitian ini menggunakan teknik sampel yaitu sampel jenuh. Menurut Sugiyono (2016:85), "Sampel jenuh adalah teknik penentuan sampel bila semua anggota populasi digunakan sebagai sampel. Karena peneliti mengambil seluruh jumlah populasi untuk dijadikan sebagai sampel penelitian". Jadi, jumlah populasi dan jumlah sampel yang digunakan untuk pengumpulan data yaitu sebanyak 121 siswa.

Teknik Pengumpulan Data

Angket/kuesioner dan dokumentasi Instrumen Penelitian
Pada penelitian ini, peneliti menggunakan instrumen penelitian berupa angket/kuesioner dan hasil belajar siswa. Kuesioner adalah pengumpulan data yang dilakukan dengan cara memberi seperangkat pertanyaan atau pernyataan tertulis kepada responnden untuk dijawabnya (Sugiyono, 2016:142). Menurut Arikunto, (2013:194), "Kuesioner adalah sejumlah pertanyaan tertulis yang digunakan untuk memperoleh informasi dari responden dalam arti laporan tentang pribadinya atau hal-hal yang ia ketahui". Kuesioner ini digunakan untuk memperoleh data tentang motivasi belajar siswa. Hasil belajar adalah perubahan yang mengakibatkan manusia berubah dalam sikap dan tingkah lakunya (Winkel dalam Susanto, 2017:45). Hasil belajar dapat pula diartikan sebagai perolehan hasil dari perubahan tingkah laku siswa yang menyangkut aspek kognitif, afektif dan psikomotor. Hasil belajar ini digunakan sebagai alat ukur untuk mengetahui sejauh mana kemampuan siswa.

\section{Teknik Analisis Data}

Teknik analisis data yang peneliti lakukan dalam penelitian ini adalah sebagai berikut:

1. Peneliti melakukan pemeriksaan serta pemberian skor pada angket yang telah diisi oleh siswa berdasarkan skala Likert yang telah ditentukan.

2. Kemudian, peneliti melakukan tabulasi data menggunakan microsoft excel.

3. Selanjutnya, peneliti menghitung nilai rata-rata angket dengan menggunakan bantuan microsoft excel.

4. Kemudian, peneliti melakukan tabulasi hasil belajar bahasa Indonesia siswa kelas X.

5. Setelah itu, data angket telah didapatkan peneliti melakukan uji prasyarat analisis yaitu uji normalitas dan uji linearitas.
HASIL
PENELITIAN
DAN 
Hasil penelitian yang telah dilakukan peneliti di Sekolah Menegah Kejuruan Maitreyaawira Tanjungpinang akan dibahas pada bab ini. Pada penelitian ini, peneliti menggunakan 5 kelas yaitu $X$ AK 1, X AK 2, X TKJ 1, X TKJ 2, dan X PMS. Pada setiap kelas tersebut, seluruh siswa dijadikan sebagai sampel penelitian dengan total keseluruhan yaitu sebanyak 121 siswa. Data yang diperoleh dari penelitian ini merupakan kuantitatif yang dikumpulkan oleh peneliti dengan teknik pengumpulan data melalui angket motivasi belajar yang akan diperoleh skor angket. Kemudian, peneliti mengambil data hasil belajar Bahasa Indonesia siswa yang diperoleh dari guru mata pelajaran Bahasa Indonesia.

Selanjutnya, peneliti melakukan penelitian selama dua hari untuk mendapatkan data angket. Kemudian pada akhir semester ganjil, peneliti kembali ke sekolah untuk memperoleh hasil belajar bahasa Indonesia siswa. Sebelum melakukan penelitian, peneliti melakukan uji coba instrumen angket terlebih dahulu. Uji coba instrumen dilakukan oleh validator dengan memberikan lembar validasi yang berhubungan dengan indikator angket. Hari pertama, peneliti menyebarkan angket motivasi belajar di tiga kelas yaitu kelas X TKJ 1, X AK 2 dan X PM. Kemudian pada hari kedua, peneliti kembali menyebarkan angket motivasi belajar di dua kelas selanjutnya yaitu kelas X TKJ 2 dan X AK 1.

Setelah selesai melakukan penyebaran angket pada seluruh kelas $\mathrm{X}$, peneliti mengolah data yang telah didapatkan. Pengolahan data pada penelitian ini menggunakan uji Wilcoxon untuk mengetahui ada tidaknya pengaruh antara motivasi belajar terhadap hasil belajar bahasa Indonesia kelas X SMK Maitreyawira Tanjungpinang Tahun Ajaran 2019/2020.

\section{Hasil Penelitian}

\section{Hasil Angket Motivasi Belajar Siswa Kelas X SMK Maitreyawira Tanjungpinang Tahun Ajaran 2019/2020}

Angket penelitian tersusun dari 20 pernyataan yang sudah disusun berdasarkan kisi-kisi angket motivasi belajar serta telah dilakukan validasi oleh validator. Peneliti menggunakan skala likert dalam teknik penilaian angket yang diberi skor 1, 2, 3, dan 4 . Dalam penelitian ini, peneliti menggunakan angket tertutup yang setiap pernyataan akan diberikan skor sesuai yang telah ditentukan. Pernyataan yang telah disediakan oleh peneliti, merupakan pernyataan positif dan negatif.

Pada pernyataan positif skor yang diberikan yaitu 4, 3, 2, dan 1. Kemudian, pada pernyataan negatif skor yang diberikan yaitu 1, 2, 3 dan 4 . Keterangan dari pernyataan positif yang memiliki skor 4 yaitu sangat setuju, skor 3 yaitu setuju, skor 2 tidak setuju, dan skor 1 yaitu sangat tidak setuju. Selanjutnya, pernyataan negatif skor yang diberikan yaitu 1, 2, 3, dan 4. Pada pernyataan negatif yang memiliki skor 1 yaitu sangat setuju, skor 2 yaitu setuju, skor 3 tidak setuju, dan skor 4 yaitu sangat tidak setuju.

Berdasarkan rekapitulasi skor menggunakan skala Likert total skor angket motivasi belajar siswa kelas $\mathrm{X}$ SMK Maitreyawira Tanjungpinang Tahun Ajaran 2019/2020 yang diperoleh berbeda-beda. Total skor angket motivasi belajar dari 121 sampel diperoleh rata-rata skor yaitu 60,36. Total skor motivasi belajar dimulai dari nilai terendah yaitu 47 sampai dengan nilai tertinggi yaitu 74. Berikut adalah rangkuman skor angket yang diperoleh siswa berdasarkan total skor dan berapa jumlah sampelnya.

Hasil total skor angket motivasi belajar yang telah dirincikan di atas skor 58 dan 61 adalah skor terbanyak 
yang diperoleh siswa yaitu 11 siswa pada masing-masing skor. Sedangkan skor tertinggi yaitu 74 yang diperoleh sebanyak 1 siswa. Skor terendah yaitu 47 yang diperoleh sebanyak 2 siswa.

Hal ini dapat dirincikan pula siswa yang mendapatkan total skor 47 sampai 49 dapat dikatakan cukup yang diperoleh sebanyak 4 siswa. Kemudian, siswa yang mendapatkan total skor 50 sampai 69 dapat dikatakan baik yang diperoleh sebanyak 110 siswa. Selanjutnya, siswa yang mendapatkan total skor 70 sampai 74 dapat dikatakan sangat baik yang diperoleh sebanyak 7 siswa. Berdasarkan hal tersebut, dapat disimpulkan bahwa hasil yang telah diperoleh masih dikatakan baik dan termotivasi.

\section{Hasil Belajar Bahasa Indonesia Siswa Kelas X SMK Maitreyawira Tanjungpinang Tahun Ajaran 2019/2020}

Hasil belajar Bahasa Indonesia diperoleh dari nilai ujian semester ganjil Siswa Kelas X SMK Maitreyawira Tanjungpinang Tahun Ajaran 2019/2020. Data nilai ujian semester ganjil diperoleh dari guru mata pelajaran Bahasa Indonesia kelas $X$. Setelah data telah diperoleh peneliti, peneliti mencari nilai rata-rata hasil belajar bahasa Indonesisa siswa. Diketahui rata-rata hasil belajar Bahasa Indonesia siswa yaitu 79,17 atau dibulatkan menjadi 79. Nilai yang diperoleh siswa mulai dari nilai terendah yaitu 70 dan nilai tertinggi 97 .

Hasil belajar siswa yang telah dirincikan di atas, nilai 73 adalah nilai terbanyak yang diperoleh siswa yaitu 23 siswa. Sedangkan nilai tertinggi yaitu 97 yang diperoleh sebanyak 1 siswa. Skor terendah yaitu 70 yang diperoleh sebanyak 4 siswa.

\section{Uji Prasyarat Analisis}

Uji prasyarat analisis digunakan untuk mengetahui apakah analisis data untuk menguji hipotesis dapat dilanjutkan atau tidak. Setelah melakukan uji prasyarat analisis dapat mengetahui uji statistik apa yang digunakan. Dalam penelitian ini, uji prasayarat yang digunakan yaitu uji normalitas dan uji linearitas.

\section{a. Hasil Uji Normalitas}

Uji nomalitas digunakan untuk mengetahui apakah data yang telah diperoleh berdistribusi normal atau tidak. Bila data berdistribusi normal, maka digunakan uji statistik berjenis parametrik. Sedangkan bila data tidak berdistribusi normal, maka digunakan uji statistika nonparametrik (Siregar, 2014:153). Uji normalitas pada penelitian ini yaitu menggunakan uji kolomograv-Smirnov dengan menggunakan bantuan program SPSS versi 24. Data dikatakan berdistribusi normal apabila hasil uji statistik menunjukkan nilai signifikansi hitung lebih besar dari nilai signifikansi yang digunakan yaitu 0,05 .

Berdasarkan hasil output SPSS versi 24, diketahui nilai Asymp.sig (2tailed) yaitu 0,000 . Kaidah pengujiannya yaitu dapat dikatakan data berdistribusi normal apabila nilai signifikansi > dari 0,05 . Sebaliknya, dikatakan data tidak berdistribusi normal apabila nilai signifikansi lebih kecil dari 0,05. Oleh karena itu, berdasarkan hasil yang diperoleh nilai Asymp.sig (2-tailed) yaitu $0,000<$ dari 0,05 , sehinggaa syarat data berdistribusi normal tidak terpenuhi. Maka, peneliti menggunakan statistik nonparametrik untuk menjawab penelitian ini karena dalam statistik nonparametrik tidak mewajibkan data berdsitribusi normal.

\section{b. Hasil Uji Linearitas}

Uji linearitas digunakan untuk mengetahui apakah antara variabel bebas dengan variabel terikat mempunyai hubungan linear (Siregar, 2014:178). Selain itu, menurut Sugiyono (2015:265), "Linearitas adalah apakah garis regresi antara $\mathrm{X}$ dan $\mathrm{Y}$ 
membentuk garis linear atrau tidak". Jadi, uji linearitas bertujuan untuk mengetahui apakah ada hubungan linear antara variabel bebas (X) terhadap variabel terikat (Y). Kriteria uji linearitas adalah apablia $F_{\text {hitung }}$ sama dengan atau lebih kecil dari $\mathrm{F}_{\text {tabel }}$ pada taraf signifikansi 5\% maka hubungan variabel bebas (X) terhadap variabel terikat (Y) dinyatakan linear. Berdasarkan keterangan di output SPSS versi 24, diketahui bahwa $F_{\text {hitung }}$ yaitu sebesar 0,395 dan nilai $F_{\text {tabel }}$ yaitu 1,62. Kriteria pengujian linearitas $\mathrm{F}_{\text {hitung }} 0,395<$ $\mathrm{F}_{\text {tabel }} 1,62$ pada taraf signifikansi $5 \%$ maka hubungan antara motivasi belajar terhadap hasil belajar bahasa Indonesia dinyatakan linear.

\section{Uji Wilcoxon}

Setelah melakukan uji prasyarat analisis, dapat diketahui bahwa data yang telah peneliti peroleh tidak berdistribusi normal. Sehingga peneliti tidak dapat melakukan analisis data menggunakan statistik parametrik. Dalam penelitian ini, peneliti menggunakan statistik non parametrik untuk mengetahui ada atau tidaknya pengaruh motivasi belajar terhadap hasil belajar bahasa Indonesia siswa kela $\mathrm{X}$ SMK Maitreyawira Tanjungpinang tahun ajaran 2019/2020. Uji statistik non paramterik yang digunakan yaitu uji Wilcoxon. Uji Wilcoxon adalah uji non parametrik yang digunakan untuk dua sampel bergantungan atau berhubungan (berkorelasi).

Data yang akan diuji menggunakan uji Wilcoxon yaitu skor hasil angket motivasi belajar dengan hasil belajar bahasa Indonesia siswa. Rekapitulasi data tersebut dapat dilihat pada lampiran. Selanjutnya, peneliti melakukan uji Wilcoxon dengan menggunakan bantuan program SPSS versi 24. Dasar pengambilan keputusan uji Wilcoxon yaitu jika nilai asymp.sig $<0,05$ maka $\mathrm{Ha}$ diterima. Sebaliknya, jika nilai asymp.sig $>0,05$ maka Ha ditolak. Berdasarkan output SPSS versi 24, asymp.sig (2-tailed) bernilai 0,000 . Karena nilai $0,000<0,05$ maka dapat disimpulkan bahwa $\mathrm{Ha}$ diterima. Artinya, ada pengaruh antara motivasi belajar terhadap hasil belajar bahasa Indonesia siswa kelas X SMK Maitreyawira Tanjungpinang tahun ajaran 2019/2020.

\section{Pembahasan Hasil Penelitian}

Berdasarkan hasil dari uji Wilcoxon, hasil yang didapatkan yaitu asymp.sig. 0,000 < 0,05 dapat disimpulkan bahwa $\mathrm{Ha}$ diterima. Hal ini berarti dapat dikatakan bahwa ada pengaruh antara motivasi belajar terhadap hasil belajar bahasa Indonesia siswa kelas $\mathrm{X}$ SMK Maitreyawira Tanjungpinang tahun ajaran 2019/2020. Setiap siswa, memiliki motivasi belajar yang berbeda-beda. Motivasi belajar merupakan suatu dorongan internal dan eksternal pada siswa yang sedang belajar untuk mengadakan perubahan tingkah laku. Motivasi pada dasarnya dapat membantu dalam memahami dan menjelaskan perilaku individu, termasuk individu yang sedang belajar (Uno, 2016: 23).

Berdasarkan hasil penyebaran angket motivasi belajar, didapatkan bahwa motivasi yang dimiliki siswa kelas X SMK Maitreyawira Tanjungpinang berbedabeda, hal ini dapat dilihat dari perolehan hasil angket yang telah diisi oleh siswa yang mendapatkan total skor bervariasi. Berdasarkan hal tersebut, dapat dilihat bahwa ada siswa yang memiliki motivasi yang kuat ada pula yang tidak. Bahkan ada siswa yang termotivasi dari luar dan ada juga yang tidak. Ada tidaknya siswa yang termotivasi dapat disimpulkan dari beberapa pernyataan yang telah dijabarkan pada angket. Tidak semua siswa yang yakin bahwa dengan belajar bahasa Indonesia dapat membantu mereka dalam mengembangkan cita-cita.

Berdasarkan hasil angket pada kode sampel 100, siswa tersebut tidak meyakinkan dirinya bahwa pelajaran bahasa Indonesia dapat membantu dalam 
mengembangkan cita-cita. Hal tersebut dibuktikan dengan jawaban siswa pada nomor 1 yang mendapatkan skor 2 dalam kategori tidak setuju. Namun, berbeda dengan kode sampel 016, siswa tersebut menjawab sangat setuju dan mendapatkan skor 4 pada pernyataan nomor 1 .

Selanjutnya, tidak semua siswa yang memotivasi diri untuk selalu memperoleh hasil belajar yang memuaskan setiap belajar bahasa Indonesia, ada pula siswa yang tidak yakin akan memperoleh hasil belajar yang memuaskan.

Berdasarkan hasil angket pada kode sampel 121, siswa tersebut memotivasi diri bahwa akan memperoleh nilai yang memuaskan ketika belajar bahasa Indonesia. Hal tersebut dibuktikan dengan jawaban pada pernyataan nomor 2 dan 4 yang diberi skor 4 dengan kategori sangat setuju. Kemudian, pada kode sampel 014, siswa tersebut tidak yakin bahwa akan memperoleh nilai yang memuaskan. Hal tersebut dibuktikan dengan jawaban siswa yang memperoleh skor 2 dengan kategori tidak setuju.

Selanjutnya, tidak semua siswa memotivasi dirinya untuk memperbaiki ketika memperoleh nilai jelek. Hal ini dapat dilihat pada pernyataan nomor 3 yang menyatakan bahwa apabila siswa mendapatkan nilai jelek, maka tidak akan belajar untuk memperbaikinya. Berdasarkan hasil angket yang didapatkan ada siswa yang menjawab sangat setuju dan ada siswa yang menjawab sangat tidak setuju.

Berdasarkan hasil angket pada kode sampel 025, siswa tersebut menjawab pernyataan nomor 3 dengan kategori sangat setuju dan mendapatkan skor 1 . Berbeda dengan kode sampel 053, siswa tersebut mendapatkan skor 4 dengan kategori sangat tidak setuju. Pada pernytaan nomor 3 ini merupakan pernyataan negatif. Jadi, apabila siswa menjawab sangat setuju maka akan memperoleh skor rendah dan jika siswa menjawab sangat tidak setuju maka akan memperoleh skor tinggi atau 4.

Selanjutnya, dalam mengatasi tugas serta soal yang diberikan oleh guru, tidak semua siswa yang mampu memecahkan dan langsung mengerjakannya. Namun, tidak menutup kemungkinan pada siswa yang mampu menyelesaikan tugas dan langsung mengerjakannya.

Berdasarkan hasil angket pada kode sampel 021, siswa tersebut menyatakan bahwa merasa lega jika mampu mengerjakan tugas yang sulit. Hal tersebut dibuktikan dengan jawaban siswa pada nomor 5 yang diberi skor 4 dengan kategori sangat setuju. Berarti siswa tersebut merasa lega ketika mampu memecahkan tugas yang diberikan oleh guru. Kemudian, siswa ada yang tidak langsung mengerjakan ketika diberikan tugas. Hal tersebut dibuktikan dengan jawaban pada pernyataan nomor 6 yang diberi skor 1 dengan kategori sangat setuju. Kemudian, pada kode sampel 048 siswa tersebut langsung mengerjakan ketika diberikan tugas. Hal tersebut dibuktikan dengan jawaban siswa yang memperoleh skor 3 dengan kategori tidak setuju.

Berdasarkan hasil uji Wilcoxon, motivasi belajar mempunyai pengaruh positif terhadap hasil belajar bahasa Indonesia. Hal ini didasari bahwa di dalam dunia pendidikan khususnya dalam kegiatan belajar mengajar di dalam kelas, motivasi adalah salah satu upaya untuk mendorong siswa meningkatkan semangat dalam memperoleh hasil belajar bahasa Indonesia. Dalam meningkatkan hasil belajar bahasa Indonesia siswa, keyakinan dan persiapan serta peran guru juga memberikan pengaruh. Berdasarkan hal tersebut, dapat dilihat pada tabel rekapitulasi pernyataan angket. Hasil rekapitulasi angket tersebut didapati berdasarkan penggunaan skala Likert.

Skala Likert digunakan untuk mengukur sikap, pendapat dan persepsi seseorang atau sekelompok orang tentang 
fenomena sosial. Jawaban setiap item instrumen yang menggunakan skala ini, mempunyai gradasi dari sangat positif menjadi sangat negatif. Dalam skala likert, sudah disediakan beberapa kata-kata untuk dijadikan sebagai pilihan jawaban.

Berdasarkan tabel 12, pada indikator cita-cita atau aspirasi siswa terdapat di dalam pernyataan 1, 2, 3, dan 4 . Pernyatan pertama jumlah sampel yang menjawab sangat setuju sebanyak 13 sampel atau dapat dikatakan sebesar $11 \%$, yang menjawab setuju sebanyak 99 sampel atau dapat dikatakan sebesar $82 \%$, dan menjawab tidak setuju sebanyak 9 sampel atau dapat dikatakan sebesar 7\%. Oleh karena itu, dapat disimpulkan bahwa pernyataan tersebut siswa setuju jika bahasa Indonesia dapat membantu dalam mengembangkan cita-cita.

Kemudian, pada pernyataan kedua jumlah sampel yang menjawab sangat setuju sebanyak 21 sampel atau dapat dikatakan sebesar $17 \%$, yang menjawab setuju sebanyak 93 sampel atau dapat dikatakan sebesar $77 \%$, dan menjawab tidak setuju sebanyak 7 sampel atau dapat dikatakan sebesar 6\%. Oleh akrena itu dapat disimpulkan bahwa hampir keseluruhan siswa yakin akan mendapatkan nilai yang memuaskan.

Selanjutnya, pada pernyataan ketiga yang merupakan pernyataan negatif, jumlah sampel yang menjawab sangat tidak setuju sebanyak 43 sampel atau dapat dikatakan sebesar $36 \%$, yang menjawab tidak setuju sebanyak 72 sampel atau dapat dikatakan sebesar $60 \%$, dan menjawab setuju dan sangat setuju sebesar $4 \%$. Hal ini membuktikan bahwa siswa akan belajar untuk memperbaiki nilai ketika mendapatkan nilai jelek.

Pada pernyataan keempat, jumlah sampel yang menjawab sangat setuju sebanyak 11 sampel atau dapat dikatakan sebesar 10\%, yang menjawab setuju sebanyak 61 sampel atau dapat dikatakan sebesar $50 \%$, dan menjawab tidak setuju dan sangat tidak setuju sebanyak 49 sampel atau dapat dikatakan sebesar $40 \%$. Berdasarkan hasil tersebut dapat disimpulkan bahwa hampir keseluruhan siswa yakin akan mendapatkan nilai tinggi pada mata pelajaran bahasa Indonesia.

Berdasarkan keempat pernyataan tersebut, dapat disimpulkan bahwa pada indikator cita-cita dan aspirasi siswa, siswa sangat memiliki motivasi yang kuat. Hal ini dikarenakan sebanyak $70 \%$ sampel menyatakan bahwa siswa memiliki motivasi terhadap cita-cita dan aspirasi dan $30 \%$ sampel menyatakan bahwa siswa kurang memiliki motivasi terhadap citacita dan aspirasinya. Oleh sebab itu, hampir keseluruhan siswa termotivasi sehingga dapat dikatakan siswa memiliki motivasi yang kuat.

Selanjutnya, pada indikator kemampuan siswa yang terdapat pada pernyataan nomor 5, 6, dan 7. Pada pernyataan kelima, jumlah sampel yang menjawab sangat setuju dan setuju sebanyak 118 sampel atau dapat dikatakan sebesar $98 \%$, yang menjawab tidak setuju dan sangat tidak setuju sebanyak 3 sampel atau dapat dikatakan sebesar $2 \%$. Berdasarkan hal tersebut, dapat ditarik kesimpulan bahwa siswa merasa lega ketika mampu menyelesaikan tugas yang sulit.

Pada pernyataan keenam yang merupakan pernyataan negatif, jumlah sampel yang menjawab sangat setuju sebanyak 9 sampel atau dapat dikatakan sebesar 8\%, yang menjawab setuju sebanyak 38 sampel atau sebesar $31 \%$, yang menjawab tidak ssetuju sebanyak 59 sampel atau dapat dikatakan sebesar $49 \%$, dan yang menjawab sangat tidak setuju sebanyak 12\%. Hal ini membuktikan bahwa lebih banyak siswa yang langsung mengerjakan ketika mendapatkan tugas dari guru.

Kemudian, pada pernyataan ketujuh jumlah sampel yang menjawab sangat setuju dan setuju sebanyak 110 sampel atau dapat dikatakan sebanyak 90\% dan yang menjawab tidak setuju dan 
sangat tidak setuju sebanyak 11 sampel atau dapat dikatakan sebesar $10 \%$. Berdasarkan hal tersebut, dapat dikatakan bahwa siswa selalu menggunakan bahasa Indonesia dalam berbagai kesempatan.

Berdasarkan ketiga pernyataan tersebut, dapat disimpulkan bahwa pada indikator kemampuan siswa, siswa sangat memiliki motivasi yang kuat. Hal ini dikarenakan sebanyak $69 \%$ sampel menyatakan bahwa siswa memiliki motivasi terhadap kemampuan siswa dan $31 \%$ sampel menyatakan bahwa siswa kurang memiliki motivasi terhadap kemampuan siswa. Oleh sebab itu, hampir keseluruhan siswa termotivasi sehingga dapat dikatakan siswa memiliki motivasi yang kuat.

Kemudian pada indikator kondisi siswa yang terdapat pada pernyataan nomor 8, 9 dan 10. Pada pernyataan kedelapan, siswa yang menjawab sangat setuju dan setuju sebanyak 91 sampel atau dapat dikatakan sebesar $75 \%$, yang menjawab tidak setuju dan sangat tidak setuju sebanyak 30 sampel atau dapat dikatakan sebesar 25\%. Berdasarkan hal tersebut, dapat disimpulkan bahwa hampir seluruh siswa selalu mempersiapkan diri ketika akan belajar bahasa Indonesia. Pernyataan kesembilan yang merupakan pernyaataan negatif, siswaa yang menajawab sangat setuju dan setuju sebanyak 36 sampel atau sebesar 30\%, yang menjawab tidak setuju dan sangat tidak setuju sebanyak 85 sampel atau sebesar $70 \%$. Hal ini dapat dikatakan bahwa lebih banyak siswa yang tidak mudah putus asa ketika tidak dapat menjawab soal.

Selanjutnya, pada pernyataan nomor sepuluh siswa yang menjawab sangat setuju dan setuju sebanyak 79 sampel atau sebesar $65 \%$, yang menjawab tidak setuju dan sangat tidak setuju sebanyak 42 sampel atau sebesar $35 \%$. Dalam hal ini, berarti siswa tetap menguatkan diri dan semangat belajar walaupun dalam kondisi kurang sehat.
Berdasarkan ketiga pernyataan tersebut, dapat disimpulkan bahwa pada indikator kondisi siswa, siswa sangat memiliki motivasi yang kuat. Hal ini dikarenakan sebanyak $58 \%$ sampel menyatakan bahwa siswa memiliki motivasi terhadap kondisi siswa dan $42 \%$ sampel menyatakan bahwa siswa kurang memiliki motivasi terhadap kondisi siswa. Oleh sebab itu, lebih dari setengah siswa termotivasi sehingga dapat dikatakan siswa memiliki motivasi yang kuat.

Pada indikator kondisi lingkungan siswa yang mencakup pernyataan nomor 11, 12 dan 13. Pada pernyataan kesebelas yang merupakan pernyataan negatif, siswa yang menjawab sangat setuju dan setuju sebanyak 14 sampel atau sebesar 12\%, yang menajwab tidak setuju dan sangat tidak setuju sebanyak 107 sampel atau sebesar $88 \%$. Berdasarkan hal tersebut dapat disimpulkan bahwa ruangan tidak memengaruhi semangat belajar siswa. Walaupun ruangan dingin siswa tidak terpengaruh untuk bermalas-malasan.

Kemudian, pada pernyataan keduabelas, siswa yang menjawab sangat setuju dan setuju sebanyak 88 sampel atau sebessar $73 \%$, yang menajwab tidak setuju dan sangat tidak setuju sebanyak 33 sampel atau sebesar $27 \%$. Hal ini membuktikan bahwa dengan adanya siswa yang aktif maka akan menimbulkan semangat pada siswa yang lainnya. Pada pernyataan ketigabelas, siswa yang menjawab sangat setuju dan setuju sebanyak 43 sampel atau sebesar $36 \%$, yang menjawab tidak setuju dan sangat tidak setuju sebanyak 78 sampel atau sebesar $64 \%$. Berdasarkan hal tersebut, siswa banyak yang tidak setuju jika berbicara menggunakan bahasa Indonesia ketika berbicara dengan orangtua di rumah.

Berdasarkan ketiga pernyataan tersebut, dapat disimpulkan bahwa pada indikator kondisi lingkungan siswa, siswa sangat memiliki motivasi yang kuat. Hal ini dikarenakan sebanyak $62 \%$ sampel 
menyatakan bahwa siswa memiliki motivasi terhadap kondisi lingkungan siswa dan $38 \%$ sampel menyatakan bahwa siswa kurang memiliki motivasi terhadap kondisi lingkungan siswa. Oleh sebab itu, lebih dari setengah siswa termotivasi sehingga dapat dikatakan siswa memiliki motivasi yang kuat.

Selanjutnya, pada indikator unsurunsur dinamis dalam belajar dan pembelajaran yang mencakup pernyataan nomor 14, 15 dan 16. Pada pernyatan keempatbelas, siswa yang menjawab sangat setuju dan setuju sebanyak 116 sampel atau sebesar $96 \%$, yang menjawab tidak setuju sebanyak 5 sampel atau sebesar 4\%. Hal ini membuktikan hawa dengan adanya tayangan video mampu menambah semangat dalam kegiatan belajar mengajar. Pada pernyataan kelimabelas, siswa yang menjawab sangat steuju dan setuju sebanyak 81 sampel atau sebesar $67 \%$, yang menjawab tidak setuju dan sangat tidak setuju sebanyak 40 sampel atau sebesar $33 \%$. Hal ini membuktikan bahwa dengan menulis dan membaca juga dapat meningkatkan semangat untuk belajar bahasa Indonesia.

Pada pernyataan keenambelas yang merupakan pernyataan negatif, siswa yang menjawab sangat setuju dan setuju sebanyak 12 sampel atau $10 \%$, yang menajwab tidak setuju dan sangat tidak setuju sebanyak 109 sampel atau sebesar 90\%. Hal ini membutkikan bahwa dengan menggunakan bahasa ibu tidak memberikan pengaruh terhadap ketertarikan belajar bahasa Indonesia. Berdasarkan ketiga pernyataan tersebut, dapat disimpulkan bahwa pada indikator unsur-unsur dinamis dalam belajar dan pembelajaran siswa sangat memiliki motivasi yang kuat. Hal ini dikarenakan sebanyak $70 \%$ sampel menyatakan bahwa siswa memiliki motivasi terhadap unsurunsur dinamis dalam belajar dan pembelajaran siswa dan $30 \%$ sampel menyatakan bahwa siswa kurang memiliki motivasi terhadap unsur-unsur dinamis dalam belajar dan pembelajaran siswa. Oleh sebab itu, lebih dari setengah siswa termotivasi sehingga dapat dikatakan siswa memiliki motivasi yang kuat.

Selanjutnya, pada indikator upaya guru dalam membelajarkan siswa yang mencakup pernytaan nomor 17, 18, 19 dan 20. Pada pernyataan ketujuhbelas, siswa yang menjawab sangat steuju dan setuju ssebanyak 109 sampel atau sebesar 90\%, yang menjawab tidak setuju dan sangat tidak setuju sebanyak 12 sampel atau sebesar $10 \%$. Hal ini membuktikan bahwa cara mengajar guru di dalam kelas dapat memengaruhi semangat siswa dalam melaksanakan kegiatan pembelajaran.

Pada pernyataan kedelapanbelas, yang menjawab sangat setuju dan setuju sebanyak 114 sampel atau sebesar 94\%, yang menjawab tidak setuju sebanyak 7 sampel atau sebesar 6\%. Hal ini membuktikan bahwa dengan adanya penggunaan media pembelajaran dapat menciptakan suasana yang menyenangkan dan memberikan pengrauh terhaadap hasil belajar siswa. Pada pernyataan kesembilan belas yang meurpakan pernytaan negatif, siswa yang menjawab sangat setuju dan steuju sebanyak 16 sampel atau sebesar $13 \%$, yang menjawab tidak setuju dan sangat tidak setuju sebanyak 105 sampel atau sebesar $87 \%$. Hal ini membuktikan bahwa jika guru menjelaskan materi yang terlalu panjang akan menciptakan suasana belajar yang membosankan. Kemudian, pernytaan keduapuluh, siswa yang menajwab sangat setuju dan setuju sebanyak 107 sampel atau sebesar 88\%, yang menjawab tidak setuju dan sangat tidak setuju sebanyak 14 sampel atau sebesar $12 \%$. Hal ini membuktikan hawa dengan adanya pemberian hadiah membuat semangat siswa dalam belajar.

Berdasarkan keempat pernyataan tersebut, dapat disimpulkan bahwa pada indikator upaya guru dalam membelajarkan siswa sangat memiliki motivasi yang kuat. Hal ini dikarenakan sebanyak $74 \%$ sampel menyatakan bahwa 
siswa memiliki motivasi terhadap upaya guru dalam membelajarkan siswa dan $26 \%$ sampel menyatakan bahwa siswa kurang memiliki motivasi terhadap upaya guru dalam membelajarkan siswa. Oleh sebab itu, lebih dari setengah siswa termotivasi sehingga dapat dikatakan siswa memiliki motivasi yang kuat.

Berdasarkan beberapa uraian di atas, dapat disimpulkan bahwa rata-rata keseluruhan mendapatkan skor 4 dan 3 pada butir pernyataan tertentu dan mendapatkan skor 1 dan 2 pada butir pernyataan tertentu juga. Kemudian, pada pernyataan nomor 13 banyak siswa yang tidak setuju bahwa berbicara menggunakan bahasa Indonesia ketika berbicara di rumah. Namun, dalam hal ini secara keseluruhaan membuktikan bahwa motivasi belajar memberikan pengaruh terhadap hasil belajar bahasa Indonesia. Selain itu, berdasarkan hal tersebut dapat dikatakan bahwa besar motivasi siswa yaitu 56\%. Oleh karena itu, dapat dikatakan motivasi belajar siswa cukup kuat dikarenakan lebih dari setengah siswa termotivasi. Berdasarkan hasil yang didapat tersebut, dapat dilihat motivasi yang kuat terdapat pada indikator kedelapan yaitu upaya guru dalam membelajarkan siswa. Pada indikator ini, setelah direkapitulasi mendapatkan persentase sebesar $74 \%$. Oleh karena itu dapat disimpulkan bahwaa bagi siswa, upaya guru di dalam kelas dapat meningkatkan motivasinya.

Selanjutnya, untuk melihat apakah motivasi memberikan pengaruh positif terhadap hasil belajar bahasa Indonesia, dapat kita lihat perolehan hasil belajar siswa pada ujian akhir semester. Hasil belajar seringkali digunakan sebagai ukuran untuk mengetahui seberapa jauh seseorang menguasai bahan yang telah diberikan. Hasil belajar merupakan perubahan-perubahan yang terjadi pada diri siswa, baik menyangkut kognitif, afektif dan psikomotor (Susanto, 2016:5).
Berdasarkan hasil yang didapat, dapat disimpulkan bahwa hasil belajar bahasa Indonesia, hampir keseluruhan siswa memperoleh hasil belajar di atas KKM yaitu mulai dari 70 sampai dengan 96. Jika dilihat antara skor angket dan hasil belajar yang diperoleh dapat dikatakan baik karena saling melengkapi dan hanya beberapa siswa saja yang tampak memiliki selisih yang cukup jauh. Sebagai contoh dapat dilihat pada kode sampel 026, siswa tersebut memperoleh total skor sebesar 70 yang dapat dikatakan baik. Pada kode sampel 026 ini juga mendapatkan hasil belajar yang memuaskan yaitu 90 yang dapat dikatakan tuntas di atas KKM.

Selanjutnya, pada kode sampel 121 yang memperoleh total skor angket sebesar 74, siswa tersebut juga mendapatkan hasil belajar yang cukup memuaskan yaitu 80 . Namun, tidak menutup kemungkinan ada faktor atau variabel lain yang memengaruhi hasil belajar siswa bukan hanya dari motivasi belajar. Hal ini dapat dilihat pada kode sampel 041, pada kode sampel tersbut siswa hanya mendapatkan total skor angket 47 yang dapat dikatakan cukup. Tetapi, hasil belajar yang diperoleh siswa tersebut sangat memuaskan yaitu 91 . Dalam hal ini, dapat dikatakan pula siswa tidak membutuhkan adanya motivasi tetapi, tentu saja ada faktor lain yang memengaruhi hasil belajar tersebut. Karena hanya bebarapa saja yang mengalami perbedaan antara total skor dan hasil belajar, dapat ditarik kesimpulan secara garis besar bahwa antara motivasi belajar memberikan pengaruh terhadap hasil belajar bahasa Indonesia.

\section{SIMPULAN}

Peneliti menyimpulkan bahwa motivasi belajar siswa kelas X SMK Maitreyawira Tanjungpinang Tahun Ajaran 2019/2020 dari keseluruhan sampel penelitian beejumlah 121 siswa memperoleh skor rata-rata 60,35. Sedangkan hasil belajar bahasa Indonesia siswa kelas X SMK 
Maitreyawira Tanjungpinang Tahun Ajaran 2019/2020 memperoleh nilai ratarata 79. Hasil kesimpulan dari pembahasan penelitin untuk menjawab perumusan masalah peneliti yaitu: Gambaran motivasi belajar siswa kelas X SMK Maitreyawira Tanjungpinang Tahun Ajaran 2019/2020 dapat dikatakan berbeda-beda. Berdasarkan hasil skor angket motivasi belajar yang mencakup beberapa indikator tersebut skor yang diperoleh siswa bervariasi mulai dari 47 hingga 74 . Hal tersebut dapat dikatakan bahwa siswa kadang-kadang termotivasi dan adakalanya siswa tidak termotivasi dalam belajar. Namun, berdasarkan hasil angket motivasi belajar tersebut secara keseluruhan banyak siswa mendapatkan skor 3 dan 4 dengan kategori sangat setuju dan setuju pada butir pernyataan tertentu. Ada pula yang mendapatkan skor 1 dan 2 dengan kategori sangat tidak setuju dan tidak setuju pada butir pernyataan tertentu. Berdasarkan hasil yang didapat dapat dikatakan bahwa besar motivasi siswa yaitu $56 \%$ dapat disimpulkan bahwa motivasi belajar siswa cukup kuat dikarenakan lebih dari setengah siswa termotivasi. Berdasarkan hasil yang didapat tersebut, dapat dilihat motivasi yang kuat terdapat pada indikator kedelapan yaitu upaya guru dalam membelajarkan siswa. Bagi siswa, upaya guru di dalam kelas dapat meningkatkan motivasinya.

Perolehan hasil belajar bahasa Indonesia siswa kelas $\mathrm{X}$ SMK Maitreyawira Tanjungpinang Tahun Ajaran 2019/2020 dapat dikatakan baik. Hal ini dikarenakan hasil belajar yang diperoleh tidak di bawah KKM. Banyak siswa yang mendapatkan nilai di atas 70 bahkan mencapai 96 dan ada pula siswa yang mendapatkan nilai 70 yang hanya sebatas KKM. Secara keseluruhan rata-rata hasil belajar siswa yaitu 79 .

Berdasarkan hipotesis penelitian ini yaitu "Terdapat pengaruh motivasi belajar terhadap hasil belajar bahasa Indonesia siswa kelas X SMK Maitreyawira tahun ajaran 2019/2020". Dilihat dari hasil penelitian yang telah diperoleh dapat dikatakan bahwa ada pengaruh motivasi belajar terhadap hasil belajar bahasa Indonesia siswa kelas $\mathrm{X}$ SMK Maitreyawira Tanjungpinang Tahun Ajaran 2019/2020. Berdasarkan output SPSS versi 24, asymp.sig (2-tailed) bernilai 0,000 . Karena nilai $0,000<0,05$ maka dapat disimpulkan bahwa $\mathrm{Ha}$ diterima. Artinya, ada pengaruh antara motivasi belajar terhadap hasil belajar bahasa Indonesia siswa kelas X SMK Maitreyawira Tanjungpinang tahun ajaran 2019/2020.

\section{UCAPAN TERIMA KASIH}

Terima kasih peneliti ucapkan kepada kedua orangtua peneliti yang telah memberikan semangat dan doa kepada peneliti selama ini.

\section{DAFTAR PUSTAKA}

Arikunto, Suharsimi. 20013. Prosedur Penelitian Suatu Pendekatan Praktik. Jakarta: PT Rineka Cipta.

Bangsawan, Indra. 2017. "Peningkatan Aktivitas dan Hasil Belajar Bahasa Indonesia Menggunakan Model STAD pada Siswa Kelas V SDN 49 Gedongtataan Kabupaten Pesawaran 2016/2017. (Skripsi). Universitas Lampung.

Darmawan, I Gusti Bagus. 2016. "Pengaruh Motivasi Belajar Terhadap Hasil Belajar Siswa Kelas XI Pada Mata Pelajaran Menggambar Bangunan SMK Negeri 1 Seyegen". (Skripsi). Universitas Negeri Yogyakarta.

Dimyati dan Mudjiono. 2009. Belajar dan Pembelajaran. Jakarta: Rineka Cipta.

El Khuluqo, Ihsan. 2017. Belajar dan Pembelajaran Konsep Dasar Metode dan Aplikasi Nilai-Nilai Spiritualitas dalam Proses Pembelajaran. Yogyakarta: Pustaka Pelajar. 
Husamah, dkk. 2016. Belajar \& Pembelajaran. Malang: UMM Press.

Pemerintah Indonesia. 2008. Undang-undang Republik Indonesia Nomor 20 Tahun 2003 tentang Sistem Pendidikan Nasional dan Undang-undang Republik Indonesia Nomor 14 Tahun 2005 tengang Guru dan Dosen. Jakarta: Visimedia.

Purnamasari, Titin. 2017. "Pengaruh Motivasi dan Minat Belajar Terhadap Prestasi Belajar Mata Pelajaran Memproses Perjalanan Dinas Siswa Kelas XI Administrasi Perkantoran SMK Muhammadiyah 2 Bantul Semester Gasal Tahun Ajaran 2016/2017”. (Skripsi.) Universitas Negeri Yogyakarta.

Purwanto. 2016. Evaluasi Hasil Belajar.Yogyakarta: Pustaka Pelajar.

Sanjaya, Wina. 2008. Kurikulum dan Pembelajaran. Jakarta: Prenadamedia Group.
Sardiman. 2012. Interaksi \& Motivasi Belajar Mengajar. Jakarta: Rajawali.

Siregar, Syofian. 2014. Statistik Parametrik untuk Penelitian Kuantitatif. Jakarta: Bumi Aksara

Sugiyono. 2016. Metode Penelitian Kuantitatif, Kualitatif, dan $R \& D$. Bandung: ALFABETA CV.

Sugiyono. 2015. Statistika untuk Penelitian. Bandung: Alfabeta.

Sujarweni, V. Wiratna.2015. SPSS untuk Penelitian. Yogyakarta: Pustaka Baru Perss.

Uno, Hamzah. 2016. Teori Motivasi \& Pengukurannya. Jakarta: Bumi Aksara.

Widiarti, Endah. 2018. "Pengaruh Motivasi Belajar dan Kesiapan Belajar Terhadap Hasil Belajar Mata Pelajaran Ekonomi Siswa kelas XII Ilmu-Ilmu Sosial Di SMA Negeri 2 Banguntapan Bantul”. (Skripsi). Universitas Negeri Yogyakarta. 